\title{
How Federal Farm Spending Distorts Measures of Economic Activity
}

\author{
John A. Tatom
}

LRING the 1980s, federal purchases of farm products by the Commodity Credit Corporation (CCC) have exhibited relatively large quarterly swings that have significantly affected how we interpret economic developments.' Although these purchases increase the government's inventory of fam products, they are treated as final sales to the government, insteal of inventory transactions, in the National Income and Product Accounts (NIPA). As a result, a CCC purchase increases federal purchases and final sales in the economy and reduces measured investment in farm inventory. Similar private sector thansactions, which redistribute fam products from one owner to anolher, result in offsetting changes in larm and business inventory; these transactions affect neither business imventory investment nor final sales.

This article explains the impact of CCO purchases and examines the distortions that they can produce in quatet-to-quarter movements of some important NIPA measures. It shows that adjusting for the effect of CCC purchases can aller conclusions about the shortterm performance and outlook for fedeal purchases, the farm sector and agregate production and emptoyment. The largest swings in CCC purchases on recond were recorded at the end of 1985 and early this year; hence, these recent swings have had the greatest impact on measures of inventory imvestment, federat purchases and overall final sales. A more useful perspective on NIPA measures can be oblained by adjusting these measures during quarters when large changes in $\mathrm{CCC}$ purchases ocel $\mathrm{I}^{2}$.

John A. Tatom is an assistant wice president at the Federal Reserve Bank of St. Louis. Michael L. Durbin provided research assistance.

The significance of such swings, especially as a major source of changes in federal purchases, was first noted by the Bureau of Economic Analysis (1982).

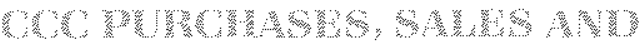

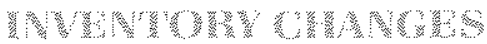

The Commodity Credit Corporation, established in 1933 as part of the Department of Agriculture, carries out the federal government's ptice stipport programs." These programs include both "nonecourse loans" and direct purchases of fam products. The former are alled nonrecourse loans because the farmer is free to deliver the pledged crop, which serves as collateral, in order to settle the loan, "The price of the commodity at which the loan is advanced is called the loan rate; it establishes a minimum price for the commodity. When the government makes such a loan, the transaction is treated in the NIPA as a purchase of farm products. As a result, these loans increase federal purchases and reduce farm inventory holdings. Repayment of the loan reverses these accounting entries. ${ }^{+}$

Direct purchases of farm products are treated in the

\footnotetext{
2More extensive discussion of the CCC can be found in the Council of Economic Advisers (1986), Herman (1978), Bureau of Economic Analysis (1982) and Wakefield (1986). The former also detasts other features of U.S. agricultural policy.

${ }^{3}$ Nonrecourse loans to tarmers are based on the governmeni-set loan rate for each farm product and the amount of the current or past product pledged against the loan as collateral. If the producerborrower cannot sell his product for more than the loan rate plus the accumulated storage costs and interest on the loan, the farmer forieits the pledged crop and the loan obligation is discharged. The farm products that are covered by the loan program include wheat, corn, barley, oats, rice, cotton, honey, peanuts, sorghum, soybeans, rye, tobacco and sugar.

"Even when the farmer pays off the loan, he reaps a benefit in the form of a short-term credit subsidy, since the interest rate on such loans is less than market rates. The CCC also supports prices of farm products by difectly purchasing certain products at ofticial support prices when such prices exceed market levels. Chief among these are such dairy products as cheese, butter and dry milk.
} 
Chat 1

\section{Purchases}

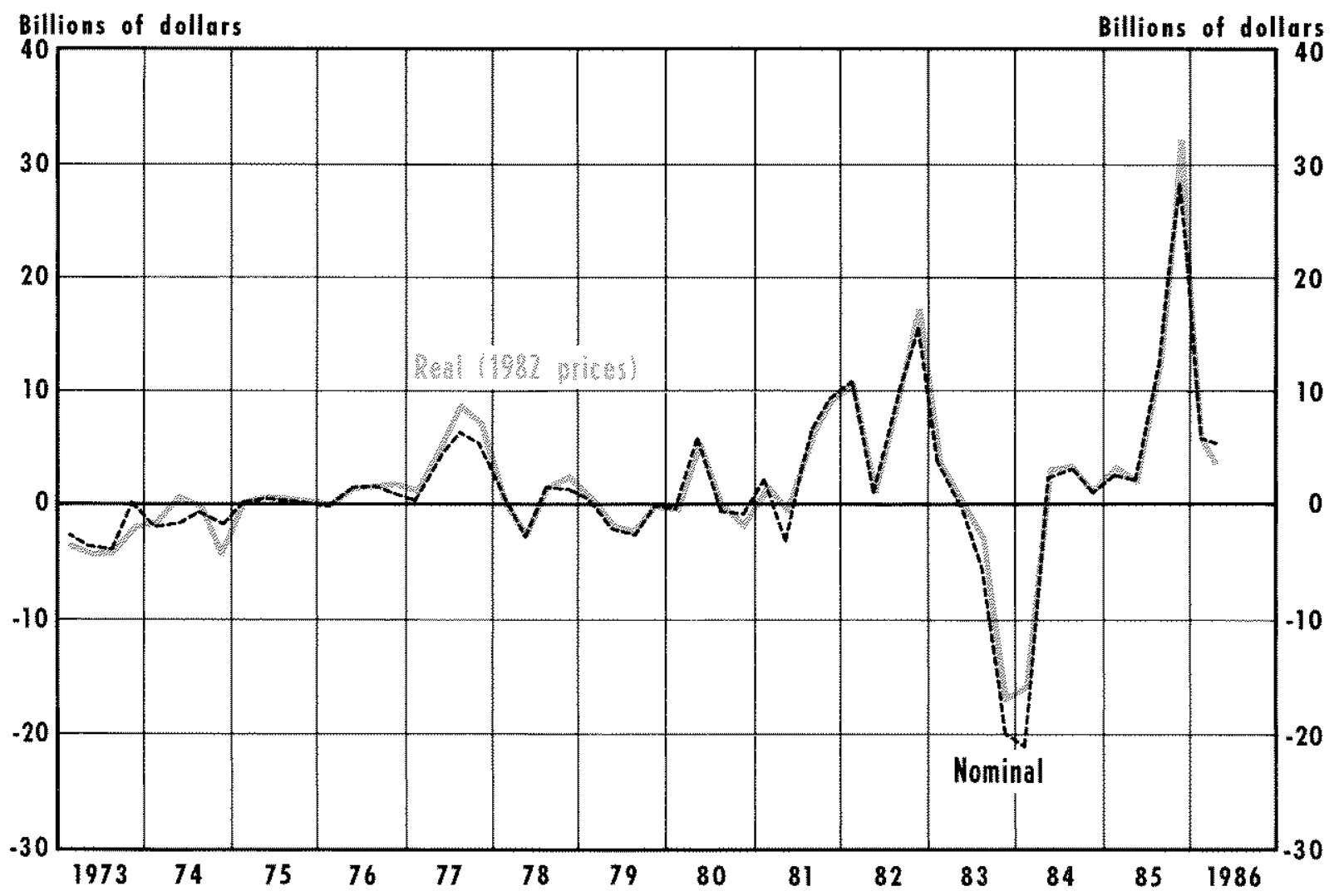

exacl same way in the NPA. Thus, commodily loans and direct commodity purchases by the foderal govermment resull in offsething changes in fecteral porrchases of goods and services and business (fam inventory investment. CNP is natifected by the tansactions because they result in no change in production.

Chart 1 shows both nominal and real 1982 pricest CCC inventory purchases from 1973 to the socond quarter of 1986. Although the nominal puchases appear small relative to curent GNP of over 44 trillion.

The independence of GNP from CCC purchases is based on two assumptions: (1) that the coverage, timing and seasonal adiustment of changes in farm inventory and CCC purchases are consistent and (2) that farmers, in general, cannot of do not respond to CCC purchases within the quarter by altering production. The former point has been made by the Bureau of Economic Analysis (1982). These second-order considerations are ignored below in order to focus solely on the measurement principles involved. the quanter-lo-quater swings are sometimes quite large in comparison to GNP novements. For examplo. in the fourth quarter of 198.3 , stech purchases rose $\$ 20.8$ billion, of 36.5 pereent of the lolal tocease in GNP during the same quater Il is also evident fom the char that movements in CCC purchases have become substantialy arger in the losos, whth the biggest swings occurring at the end of 1985 and in eaty 1986. In pant, these increased fuchuatons reflect the growing rote of federal farm programs.

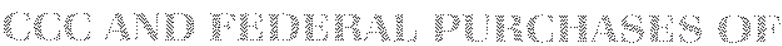

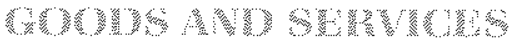

Quartedy movements in CCC purchases have had a sizable impace on the pallem of growth of fecleal purchases dung some quartes in the 1980s. Chat 2 shows the growth rates of pal fedom purbases and adjusted roal federal purolases iwheh exclude COC 
Chari 2

\section{The Growth Rate of Real Federal Purchases with and without CCC Purchases}

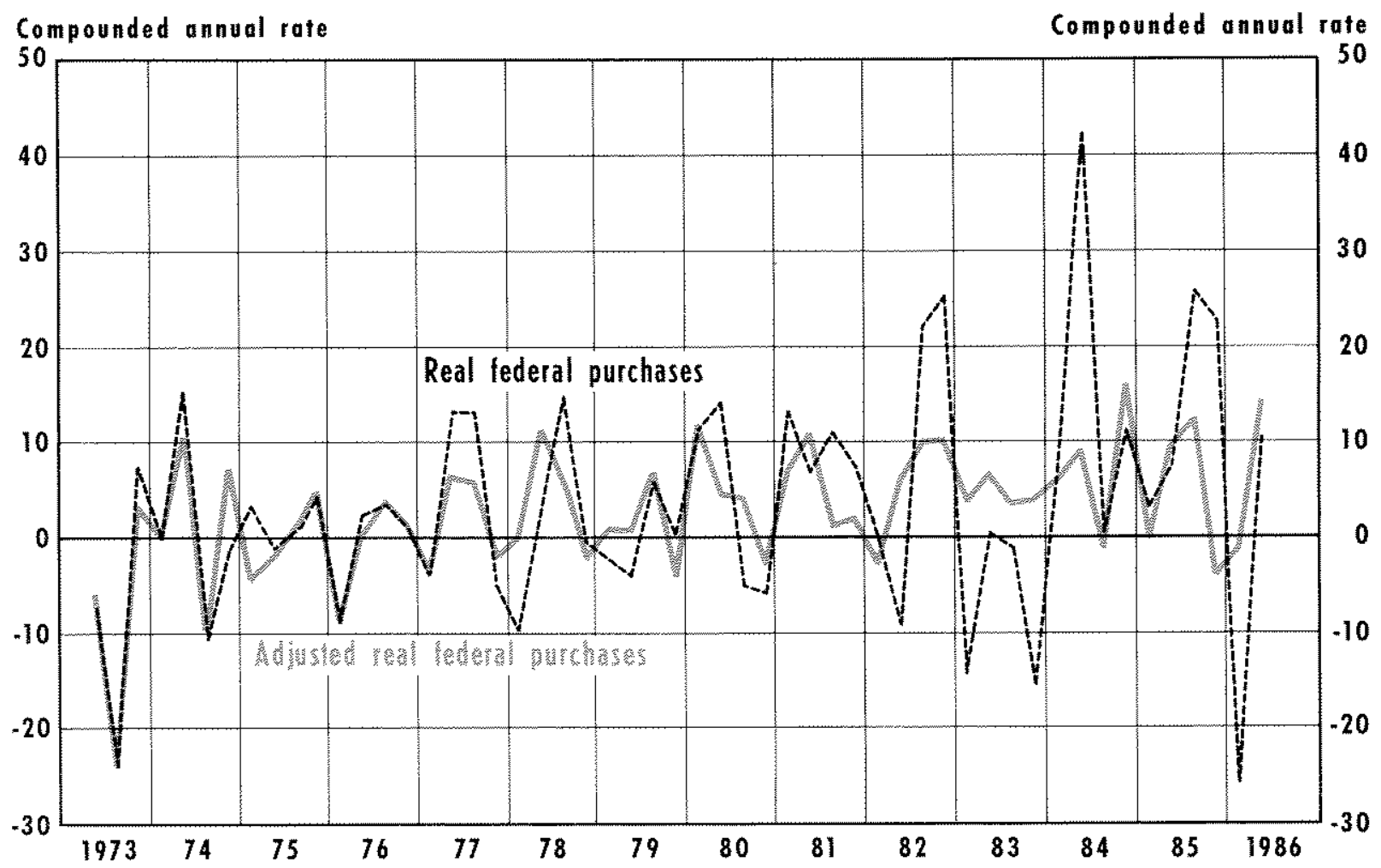

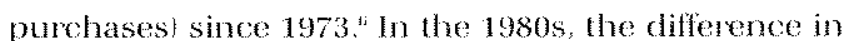
the growth rates often has been quile large and more variable. Since 1980, the tederal government genestly has been accumulating inveniory of farm products, but in 1983 and early 1984 , the payment-ln-Kind (PIK) progran led to large sales for fott quaters. These swings in CCC purchases had a matior impact on the growth mate a federal puehases, genew ally depressing it in 1983 and early 1984 and subsequently rasing it. These swings make it diffoult for analysts to interpret trends in federat spending

Another coincidental effect of CCC puchases in recent vears has been to raise the growth rate of

'Since nominal and real CCC inventory changes are not substantially different over the period since 1973, attention throughout this article is focused on real measures. Movements in the nominat counterparts of reat measures provide no additional insight and so are ignored here.

'A description and analysis of the PIK program that was in effect in 1983 and early 1984 can be found in Belongia (1983) and Rosine (1984). federal purchases during recession periods, while depressing the growth of federal purchases during the inital stages of expansions. This effect has resulted in the appeanace of a negative felationship between GNP and federal purchases, a relationship that disappears when federal purchases are adjusted for $\mathrm{CCC}$ purchases. For example, from $1 / 1980$ to $1 / 1986$, the comelation between the growth rate of real feclem purchases of goods and services including CCC purchases and of real GNP is negative $(-0.15)$; when real CCC purchases are omitted from government purchases, however, the correlation is posilve (0.04). While neither cortation is statisticaly significant, distortions caused by volatile CCC purchases an bias stalistical tests of fiscal policy's genemal effectiveness.

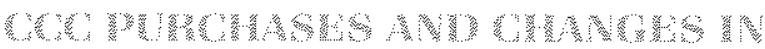

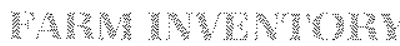

Federal purchases of farm products are offset in the 
Table 1

The Change in Farm Inventory and CCC Purchases (billions of dollars, 1982 prices)

\begin{tabular}{|c|c|c|c|c|c|}
\hline & $\begin{array}{l}\mathrm{CCC} \\
\text { purchases }\end{array}$ & $\begin{array}{l}\text { Change in } \\
\text { farth } \\
\text { inveritory }\end{array}$ & $\begin{array}{l}\text { Annual mean } \\
\text { standard } \\
\text { deviation }\end{array}$ & $\begin{array}{l}\text { Change in } \\
\text { farm inventory } \\
\text { and } \mathrm{CCC}\end{array}$ & $\begin{array}{l}\text { Annual mean } \\
\text { standard } \\
\text { deviation }\end{array}$ \\
\hline $1 / 1980$ & $\$-0.3$ & $\$-50$. & & $\$-53$ & \\
\hline II & 55 & -7.0 & $\$ 4.7$ & -1.5 & $\$-39$ \\
\hline III & 0.2 & -10.5 & 609 & 107 & $\begin{array}{r}537 \\
\end{array}$ \\
\hline IV & 20 & 3.8 & & 18 & \\
\hline $1 / 1981$ & 16 & 46 & & 6.2 & \\
\hline 11 & -08 & 112 & 4.9 & 104 & 87 \\
\hline III & 55 & 50 & 5.11 & 105 & 209 \\
\hline W & 91 & 13 & & 78 & \\
\hline $1 / 1982$ & 10.8 & $4 t$ & & 67 & \\
\hline 11 & 07 & 40 & -15 & 47 & 77 \\
\hline III & 79 & 32 & 616 & 111 & 271 \\
\hline N & 172 & -89 & & 83 & \\
\hline $1 / 1983$ & 38 & -91 & & 53 & \\
\hline il: & $-0 t$ & 69 & 63 & $-7 \emptyset$ & 105 \\
\hline III: & 31 & -157 & 932 & -18. & 601 \\
\hline IV & 172 & 6.5 & & -107 & \\
\hline $1 / 1984$ & 15.9 & 164 & & 0.5 & \\
\hline II $\quad$ & 31 & 18 & 49 & 49 & 27 \\
\hline III & 34 & 13 & 772 & 47 & 2.4 \\
\hline N & 08 & 0.0 & & 0.8 & \\
\hline $1 / 1985$ & 32 & 64 & & 96 & \\
\hline 11 & 2.0 & 78 & -20 & 9.8 & 10.3 \\
\hline III & 11.5 & -0.7 & 13.43 & 108 & 07 \\
\hline IV & 32.3 & -21.3 & & 110 & \\
\hline $1 / 1986$ & 6.4 & 29 & & 93 & $\because$ \\
\hline I\# & 4.5 & 4.1 & 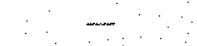 & 8.6 & $\because$ \\
\hline
\end{tabular}

GNP accounts by reductions in farm inventory. Thus, CCC purchases can distort the shortrun interpretation of changes in farm and busmess inventory. Whon the CCG purchases (sells) farm goods, farm and business inventory investment faks trisest. giving the appearance of an inventory change. of course, such an appearance is deceptive; in fact, imventory holdings have simply moved from private to federal government ownership, or vice versa.

\footnotetext{
sAn inverse relationship between business inventory investment and government purchases of goods has been noted by Weidenbaum (1959) and (1961). His analysis emphasizes the time pattern of production and delivery and the NIPA accounting of such programs. The implied lack of a contemporaneous relationship of GNP and such spending was first pointed out in these articles.
}

Table 1 shows quarterly real CCC purchases and changes in both real farm inventory and feal fam inventory plus real CCC parchases since 1979:" The mean and standard deviation of each series also are shown for each year. The pattern of changes in the overall measture of farm inventory is much smoother when CCC purchases are included than when they are not. This is especially true when relatively large changes in CCC purchases occur. Al these times, farm imventory investment swings widely in the opposite diection, such as in 1 V/1982, W/1983, 1/1984 and the

FFor the period shown in table 7 , the correlation between changes in CCC purchases (1982 prices) and changes in farm inventory investment is -0.56 , which is statistically significant at the 1 percent level. 
end of 1985. The standard deviation for farm inventory investment each year is sharply higher than that for the total farm product inventory change. This occurs because the movements of CCC purchases are offset by opposite movements in farm inventory purchases. Of course, this smoothing effect also occurs for the overall change in inventory - the sum of business (non-farm and farm) inventory change and CCC purchases.

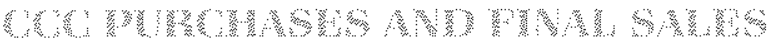

While federal purchases of farm products do not affect GNP - the value of final goods and services produced in the economy - they do affect the measurement of final sales, which equals GNP less the change in business inventory. Analysts often focus on final sales in odder to assess the strength and outlook for income, output and employment. Assessments of final sales are important both because inventory and production decisions are based on expeclations of such sales and because unexpected changes in sales are absorbed by inventory fuctuations. Thus, movements in final sales relative to production provide information on future production changes and can give rise to an inventory cycle." When sales are less than production, for example, the unsold products increase inventory. If the rise in inventory is undesired and unplanned, it will be eliminated by reducing production growth temporarily relative to that of $e x$ pected sales. Moreover, if movements in GNP reflect temporary changes in production to adjust inventory, final sales can be a more useful gatige of the outlook than current production or GNP.

CCC purchases have substantal quarter-to-quarter' effects on the measurement of final sales. This occurs

\footnotetext{
10 White the assumed independence of Ccc purchases and farm output within the quarter seems satisfactory, it might be argued that such purchases contribute to higher farm output than would othefwise occur. To test these views, "Granger-causality" tests were conducted on the quarterly change in farm sector output and the change in CCC purchases, both in 1982 prices, for the period II/1973 to II/1986. Optimal lags on the lagged dependent variable were chosen via sequential F-tests. The resulis indicate "bidirectonal causalizy": pasi CCC purchases negatively and significantly affect farm output; past changes in farm output positively and significantly raise CCC purchases. When the contemporaneous value of the change in CCC purchases is included in the farm output equation, there is no significant past CCC effect and the contemporaneous CCC term is not significant for lags on the change in CCC purchases up to 10 quarters earlier.

"The inventory cycle and its significance in U.S. business cycles from 1948 to 1976 is discussed in Tatom (1977).
}

because such purchases affect the change in business inventory but leave GNP unaffected. When CCC purchases increase, for example, measured final sales tend to rise because business (farm) inventory deches. Yet such purchases simply represent another way of holding farm inventory, not a significant in crease in overall spending on goods and services that will likely lead to increased production. Thus, if the change in business inventory is adjusted to include CCC purchases, the adjusted final sales measure obtained can more closely gauge the actual final purchases of goods and services by consumers, business. government and foreign purchasers. Chart 3 shows real final sales growth both without an adjustment and with CCC purchases sublracted from final sales.

The largest differences in the growth of final sales, adjusted for CCC purchases, occur atter 1981. In the second hall of 1982, relatively large COC purchases contributed to final sales growth. From the second to the fourth quarter of 1982, real final sales expanded at a 2.1 percent rate, higher than the 1.1 percent rate for adiusted real final sales. Subsequent reductions in the government's holding of farm product inventory through the PIK program led to an understatement of final sales growth. From the fourth quarter of 1982 to the fourth quanter of 1983 , real final sales expanded at a 3.7 percent mate, but this was below the 4.8 percent rate of adjusted real final sales growth. In effect, the transfer of farm product inventory from the government to the private sector appeared only as a net business inventory change, which understated the growth of final sales. Of course, these periods match the end of the 1981-82 recession and early part of the current expansion. Thus, the cyclical swing in measured final sales growth understates the actual acceleration in adjusted tinal sales that took place.

The most recent CCC purchases, especially in the fourth quarter of 1985 , are the largest on record. In the second quarter of 1985 and the second quarter of 1986 , real CCC purchases were $\$ 2$ billion and $\$ 4.5$ billion, respectively. Thus, in each quarter, the final sales measure was little affected by CCC puchases; over the whole year, real final sales and real final sales adjusted for CCC purchases rose 2.7 and 2.6 percent respecm tively. Moreover, the pace of overall inventory invest ment was about the same in each quarter, so that real GN grew at about the same rate over the year.

But the pattens of reat GND, real final sates and adjusted real final sales were quite different during the year. Table 2 shows these growth rates. Both final sales series show that production grew faster than sales in 


\section{Chart 3}

\section{Purchases and Real Final Sales Growth}

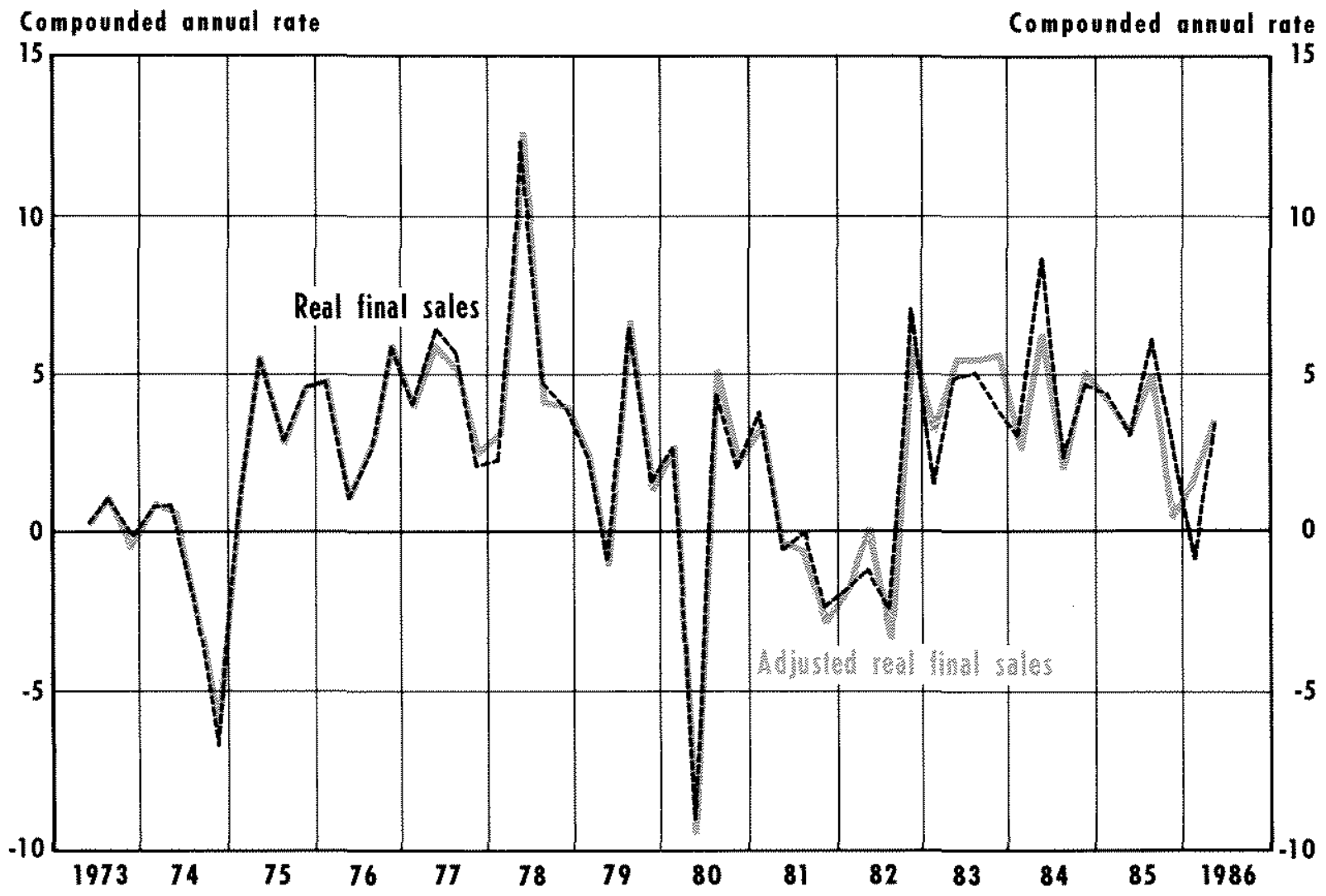

the last quarter of 1985 and first quarter of 1986.50 , not surprisingly, production growth slowed temporarily in the second quater of 1986 to eliminate excess inventory. Both final sales series also show that sales growth accelerated in the second quarter of 1986 .

The principal differences in table 2 are that sales growth in 1986 was stronger according to the adjusted series and that it accelerated for two quarters lather than one. The stronger sales growth on an adjusted basis suggests stronger growth in aggregate demand and more incentive for firms to increase production and employment than the unadjusted data indicate Also, the second quarter acceleration in final sales appears less likely to be a fluke using the adjusted series. The acceleation simply reinforces the pattern set in the previous quater, instead of appearing to be the first sign of positive sales growth since the end of 1985, as indicated in the unaljusted data.

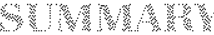

While movements in CCC purchases can be relatively large, they have had no major effects on final sales and other NIPA measures until the past few years. During recent years, the pattern of CCC purchases has had relatively large effects on measured inventory change, federal purchases and expenditures, and final sales. In 1982 and 1983 , the effect was to raise the growth of both federal spending and final sales during the last two quarters of the recession and to lower their growth in the first five quarters of the subsequent expansion. More recently, recold net purchases by the $\mathrm{CCC}$ in the last half of 1985 have given rise to a distorted pattern of sales growth, suggesting generally weaker sales than the adjusted data indiate. Analysts who focus on unadjusted data, accordingly, would understate the recent strength of aggregate demand and the short-rum prospects for growth. 
Table 2

Growth Rates of GNP and Final Sales over the Previous Year

\begin{tabular}{|c|c|c|c|}
\hline Quarter ending & Real GNP & $\begin{array}{l}\text { Real } \\
\text { final sales }\end{array}$ & $\begin{array}{l}\text { Final sales less } \\
\text { CCC putchases }\end{array}$ \\
\hline $11 / 1985$ & $41 \%$ & $61 \%$ & $50 \%$ \\
\hline N1985 & 21 & 27 & 04 \\
\hline 11986 & 38 & 13 & 16 \\
\hline $11 / 1986$ & 0.6 & 34 & 3.6 \\
\hline $11 / 1085-1 / 1986$ & 26 & 27 & 26 \\
\hline
\end{tabular}

For policy purposes, fluctuations in CCC purchases can distort quarter-to-quater movements in important NIPA measures, providing a misleading indication of the strength or weakness of federal spending, farm inventory investment and final sales. Faced with such distontions, analysts will find it useful to take more care in accounting for these quarterly movements in $\mathrm{CCC}$ purchases and their effects on key measures of economic performance.

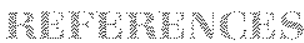

Belongia, Michael T. "Outlook for Agriculture in 1983," this Review (February 1983), pp. 14-24.

Bureas of Economic Analysis, U.S. Department of Commerce. "Special Note - The Commodily Credit Corporation in the National income and Product Accounts," Survey of Current Business (January 1982), pp. 6-7.
Council of Economic Advisers. Economic Repont of the President (U.S. Government Printing Office, February 1986), pp. 129-58.

Herman, Shelby $W$. "The Farm Sector," Bureau of Economic Analysis, U.S. Department of Commerce, Survey of Current Business (November 1978), pp. 18-26.

Rosine, John. "The Farm Sector and GNP," paper presented to the Federal Reserve Committee on Agriculture and Rural Development, Board of Governors of the Federat Reserve System, June 1, 1984, processed.

Tatom, John A. "Inventory Irvestment in the Recent Recession and Recovery," this Review (April 1977), pp. 2-9.

Wakefield, Joseph C. "Federal Farm Programs in 1986-90," Bureau of Economic Analysis, U.S. Department of Commerce, Sur. vey of Current Business (April 1986), pp. 31-35.

Weidenbaum, Murray L. "The Timing of The Economic Impact of Government Spending," National Tax Journal (March 1959), pp. $79-85$.

"The Government Spending Process and Economic Activity," The American Joumal of Economics and Sociology (January 1961), pp. 169-79. 